\title{
MODELING HABITAT SELECTION OF THE RED-FOOTED FALCON (FALCO VESPERTINUS): A POSSIBLE EXPLANATION OF RECENT CHANGES IN BREEDING RANGE WITHIN HUNGARY
}

\author{
P. FEHÉRVÁRI ${ }^{1,4^{*}}-$ A. HARNOS ${ }^{1,2}-$ D. NEIDERT ${ }^{3}-$ SZ. SOLT $^{4}-$ P. PALATITZ $^{4}$ \\ ${ }^{1}$ Department of Biomathematics and Informatics, Faculty of Veterinary Science, Szent István \\ University \\ 2 Adaptation to climate change" HAS Research Group,H-1078, István u. 2. Budapest, Hungary \\ (phone: +36-1-478-4214; fax: +36-1-478-4217) \\ ${ }^{3}$ SZIE, KTI Department of Cartography, Geoinformatics and Remote Sensing H-2103 Páter \\ Károly út 1. Gödöllö, Hungary \\ (phone: +36-28-522-000/2270; Fax:+36-28-415-383) \\ ${ }^{4}$ MME/BirdLife Hungary, Red-footed falcon Conservation Working Group H-1121 Költö utca \\ 21. Budapest, Hungary \\ (phone: +36-1-275-6247; Fax: +36-1-275-6247) \\ *Corresponding author \\ e-mail:fehervari.peter@mme.hu \\ (Received 21 $1^{\text {st }}$ March 2008; accepted $15^{\text {th }}$ May 2008)
}

\begin{abstract}
Due to a severe population decline and shrinkage of distribution range in the past decades, the red-footed falcon has gained top priority in both worldwide and Hungarian nature conservation. As a facultative colonial breeder, in Hungary, this species predominantly nests in rookeries. The number of rooks (Corvus frugilegus) has also dramatically fallen recently, but population decline did not affect the large scale breeding distribution of this species. In our study we analyzed the presence of red-footed falcons at a colony in the case of current and historical breeding ranges based on landscape scaled habitat variables. We used a potential colony home-range size, estimated from observed home-range sizes in order to determine the scale of influential habitat variables. According to our results, the primary cause of the observed range shift is the urbanization of rooks in definable regions of Hungary. The ratio of forests and open water surfaces within the potential home-range had negative, while the ratio of grasslands had a positive effect on the probability of red-footed falcon presence. None of our models predicted red-footed falcon presence at colonies outside the current breeding range, suggesting that a probable increase in redfooted falcon population numbers will not be accompanied by the expansion of the current breeding range.
\end{abstract}

Keywords: red-footed falcon, habitat, modeling, breeding range, rook, spatial GLMM

\section{Introduction}

The analysis of habitat use and selection is important for adequate, well founded planning of species based conservation management (Pearce et al., 2008, Robles et al. 2007, Noss et al. 1997). Habitat selection and habitat use data are necessary for the prediction of a species' distribution (Elith et al., 2006, Guisan 2005, Araújo 2007), for the assessment of risk factors (Xuhezi et al. 2008, Groning et al. 2007), drafting of habitat management regulations (Garcia et al. 2006, Franco et al. 2004) and for the conservation of a single species or a group of species. Habitat selection of birds of prey is a common research topic in conservation biology (Toschik 2006, Palomino \& 
Carrascal 2007, Lopez-Lopez et al. 2007, Bustamante 1997), since these birds are good environmental bioindicators (Newton 1979, Roberge \& Angelstram 2004) and are often referred to as umbrella or flagship species (Sergio 2006, Ozaki 2006).

The red-footed falcon is an endangered colonial raptor species, with a continually diminishing population, classified as near threatened by the IUCN Red List (http://www.iucnredlist.org/details/144562). The breeding range is in open, typical steppe type habitats ranging from Eastern Europe to Lake Baikal in Central Asia (del Hoyo et al. 1994). This species is a long distance migrant, with presumed wintering grounds in South-Western Africa: from the Northern parts of the South African Republic through Namibia, Botswana, Angola, Zimbabwe and Zambia (del Hoyo et al., 1994, van Zyl pers. comm.).

The territory of Hungary - which is the westernmost edge of the species' distribution range (del Hoyo et al., 1994) - is almost negligible compared to its whole distribution area, but it has considerable importance in the conservation of this small bird of prey (Bagyura \& Palatitz 2004). Hungarian nature conservation has always paid a great deal of attention to the protection of red-footed falcons, so the overall population estimates for the country are probably the most accurate throughout the world (Bagyura \& Palatitz 2004).

The first country-wide survey performed by Keve and Szíjj (1957) in the middle of the last century estimated the breeding population to be 2200-2500 pairs, while the size of the population in 2006 was estimated at 500-600 pairs (Palatitz et al. 2006). The methods used in these surveys differed markedly, therefore direct comparison cannot be made, but it is certainly true that the population had significantly decreased - possibly by up to $50 \%$ - during the past decades (Fig. 1.).

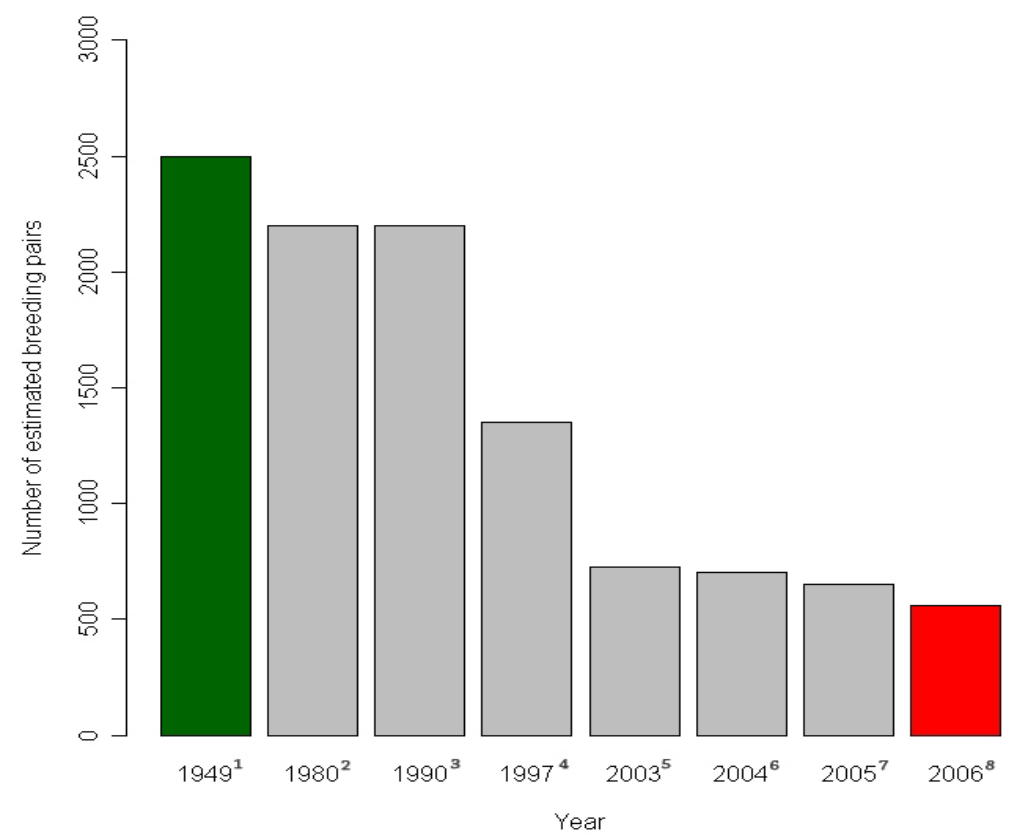

Figure 1. The estimated maximum number of breeding red-footed falcon pairs in the past 60 years. The red and green columns reflect the number of breeding pairs of Figure2. and Figure 3., respectively.

Source: ${ }^{1}$ Keve \& Szijj 1957, ${ }^{2}$ Haraszthy 1981, ${ }^{3}$ Haraszthy 1998, ${ }^{4}$ Tóth \& Marik 1999,

${ }^{5,6}$ Bagyura \& Palatitz 2004, ${ }^{7}$ Palatitz et al., 2005, ${ }^{8}$ Palatitz et al. 2006 
Beyond the overall population decline, the spatial distribution of breeding birds was found to be radically different during the 2006 survey (Fig. 2.) compared to 1949 (Fig. 3.). It is obvious that by 2006 red-footed falcons occupied almost exclusively the Great Plain region, practically deserting Transdanubia and Northern Hungary.

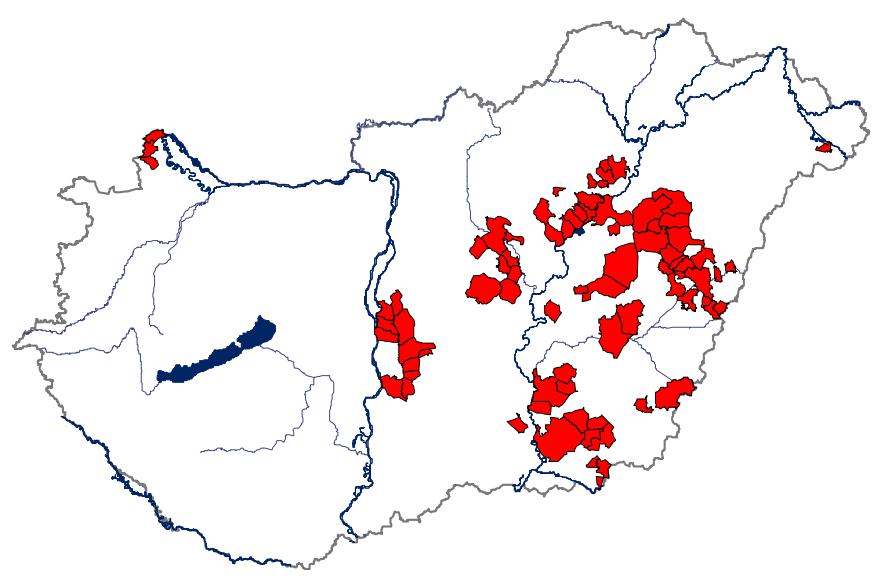

Figure 2. The distribution of red-footed falcons in Hungary according to the 2006 survey. Red polygons mark municipipaity borders where breeding pairs were recorded in colonies or as solitary pairs.

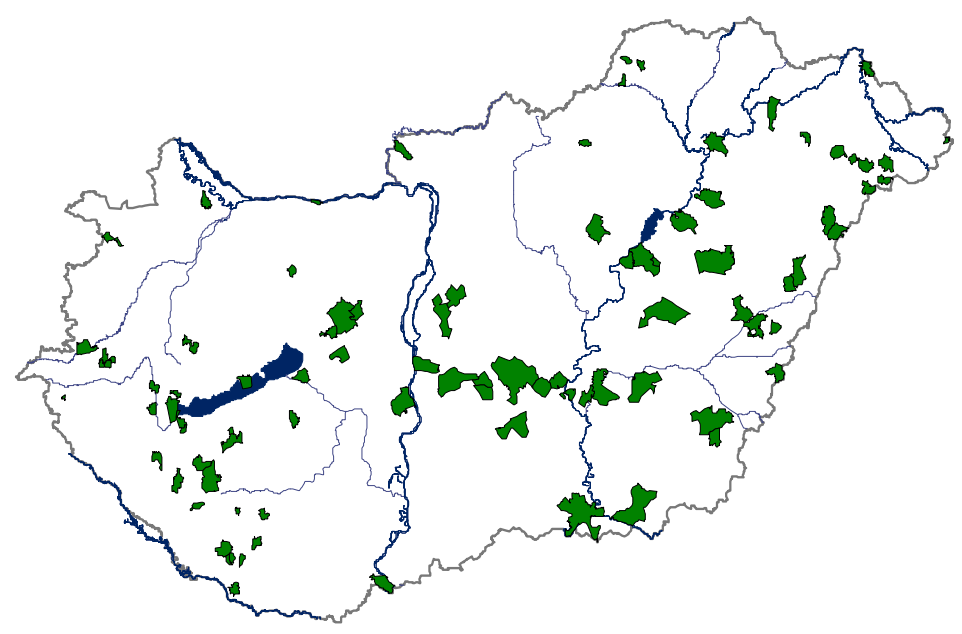

Figure 3. Distribution of red-footed falcons in Hungary according to the 1949 survey. Green polygons mark municipality borders where red-footed falcon breeding was recorded in rookeries.

The conditions for the colonial nesting of red-footed falcons are primarily provided by rookeries (Horváth 1964). The rook used to be a wide-spread, common species from the 1940's (Vertse 1943) to the 1980's (Kalotás \& Nikodémusz 1981, Kalotás 1984), but as a consequence of an intensive eradication campaign in the mid 80's, the population rapidly decreased throughout the country (Kalotás 1987, Solt 2008) from 
about 260.000 to almost 23.000 pairs in approx. 30 years. In order to halt this trend, the rook was declared protected by the Hungarian Nature Conservation Authorities in 2001.

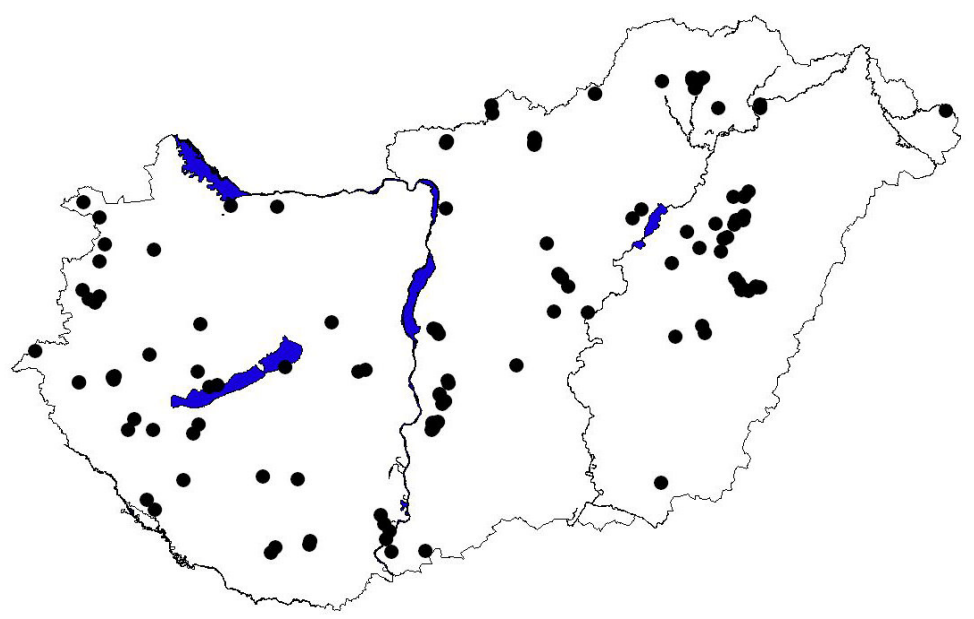

Figure 4. Rook colonies in 2006. Despite the approx. $90 \%$ decline in the rook population, the large scale distribution of rookeries was not affected.

As the result of the rook population decline, the number of rookeries suitable for the colonial nesting of red-footed falcons also decreased. In order to compensate for this loss, artificial nest box colonies are being established by the Life-Nature Red-footed falcon conservation project personnel (Solt et al. 2005, www.falcoproject.hu). Despite this large scale decrease in the number of breeding rook pairs, rookeries are still available for red-footed falcon nesting throughout Hungary (Fig. 4.). Red-footed falcon population decrease therefore can, to some degree, be explained by the crash of the rook population, but the recent changes in breeding range cannot be directly linked. In this study we analyzed the relationship between landscape scale habitat variables and the spatial distribution of colonies used by red-footed falcons in order to understand how these variables affect the current distribution pattern.

\section{Materials and methods}

As an initial step, we collected the coordinates of all colonies suitable for red-footed falcon breeding and defined the current breeding range in 2006. In the second stage we assessed the potential home-range of a red-footed falcon colony. This was carried out using habitat use analysis data deriving from a three-year radio-telemetry study. The following step was to draw the potential home-ranges around the coordinates of every colony and to intersect these with a GIS database containing habitat describing variables. The variables within the potential home-ranges of every colony were later used for statistical modelling.

\section{Data}

The geographical coordinates of colonies derived from two separate databases: the integrated population monitoring database of the red-footed falcon LIFE program, and the database of Rare and Colonial Bird species of the Hungarian Ministry of Enviorment and Water (Solt 2008). 
The analyses were carried out on two spatial scales. To be able to assess the differences between the 1949 (Fig. 3.) and 2006 breeding distribution (Fig. 2.) and to understand the pattern of colony occupation within the current breeding range, we spatially defined the "historic" and "current" breeding ranges.

We considered the whole area of Hungary as the "historic" breeding range, because the 1949 distribution (Fig. 3.) shows that there was at least one colony in every large region (apart from high altitude closed forests), therefore we did not a priori exclude any colonies based solely on its location. While the databases hold 198 potentially suitable colonies, we had to exclude the ones where the potential home-ranges protruded Hungary's border. Therefore 162 colonies: 41 colonies with red-footed falcon presence and 121 without red-footed falcon presence were used in the analysis

The current breeding range was defined based on the municipality borders of Figure 2. by applying a 500 meter buffer to the outline of the polygons and connecting the outer edges (Fig. 4.). Two municipality borders (on the Northwestern and Northeastern part of the country) were excluded from the current breeding range because they hold only four solitary pairs altogether. Therefore, the defined current breeding range holds all colonies occupied by red-footed falcons and over $99 \%$ of the solitary pairs.

\section{Defining the potential home-range of a colony}

The true home-ranges of individual red-footed falcons were estimated from the data of the LIFE program's ongoing habitat preference analysis. We radio-tagged 24 birds in the 2006 and 2007 breeding seasons with 3.5g "Biotrack TW-4" radio-tags. The birds were directly followed during their hunting, and the exact location of hunting events and other habitat use variables were recorded (see methods in: Franco et al. 2007, Tella et al.1998).

Based on the individual home-ranges, we estimated the potential home-range of a colony to be a 3000 meter radius circle, which covers at least $95 \%$ of the localization points of the studied colonies (unpublished data).

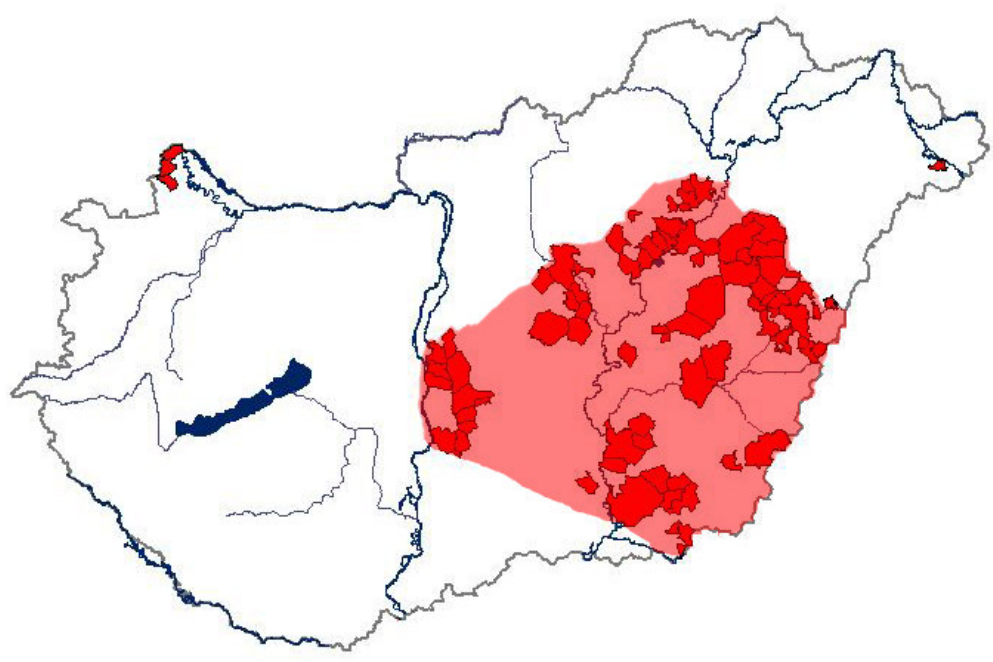

Figure 5. Defining the „current” breeding range of red-footed falcons. The red polygons shown on the map mark the municipality borders where red-footed falcon breeding occurred in 2006 according to the monitoring data. The ruby red large polygon shows the area defined as the „,current” breeding range in our analyses. 


\section{Habitat variables}

The habitat variables were extracted from the CORINE land cover frameworks GIS database. In Hungary, this database was created by SPOT4 $\mathrm{Xi}+\mathrm{M}$ type satellite images shot in 1998 and 1999. The CORINE has 79 land cover categories. The minimum area of uniform polygons is 4 ha. Although the database is relatively out of date, it is still usable to analyse certain variables due to its coarse resolution. The 79 variables were summed and transformed into 12 biologically relevant variables (Table 3.).

The potential home-range size (3000 meter radius circles) was used to obtain the spatial explanatory variables surrounding each colony. We used the size, length and number of the habitat categories within the potential home-ranges for the analyses.

Table 1. Spatial variables used to model landscape scale breeding colony occupancy of red-footed falcons

\begin{tabular}{|l|c|}
\hline \multicolumn{1}{|c|}{ Variable } & Unit \\
\hline Water canals & Meter \\
\hline Forest & $\mathrm{Ha}$ \\
\hline River & $\mathrm{Ha}$ \\
\hline Road & $\mathrm{meter}$ \\
\hline Grassland & $\mathrm{Ha}$ \\
\hline Small parcel arable land & $\mathrm{Ha}$ \\
\hline Large parcel arable land & $\mathrm{Ha}$ \\
\hline Farms & $\mathrm{pcs}$ \\
\hline Settlements & $\mathrm{Ha}$ \\
\hline Railroad & $\mathrm{meter}$ \\
\hline Water surface & $\mathrm{Ha}$ \\
\hline Wetlands & $\mathrm{Ha}$ \\
\hline
\end{tabular}

\section{Statitstics}

We used Spatial Generalized Linear Mixed Effects Models (Spatial GLMM) with logit link and binomial response to analyse the presence/absence of red-footed falcons in relation to landscape scaled habitat variables on both historic and current breeding range scales. Model selection was carried out by applying a decision tree (CART model) to all variables. The variables grouping the observations were used as explanatory variables in the Spatial GLMMs. Decision tree pruning was carried out by optimizing the complexity parameter (Faraway 2005). We categorized the variables into 5 ascending categories to aid better understanding of decision tree outputs, while we used the relative size of the same variables in the GLMMs. We fitted a spatial GLMM on the observations when the explanatory power of the decision tree was sufficient and the hierachical structure of the grouping variables was biologically interpretable. The explanatory power of the GLMMs was more or less smaller than that of the decision trees, possibly due to the spatial autocorrelation of the expalanatory variables. The CART models were unable to differentiate between artificial and natural colonies (decision tree, Cohen's $\kappa=0.23,95 \%$ Confidence Interval:-0.02, 0.47), therefore we did not distinguish colony types in the analyses.

We used the QGIS sofware (www.qgis.org) to handle and map GIS variables, and the R 2.8 sofware for data analysis (R Development Core Team 2007). The most important $\mathrm{R}$ packages and their role in the analysis are presented in Table 2. 
Table 2. Most important $R$ packages and their role used in the analyses

\begin{tabular}{l|l|l}
\hline \multicolumn{1}{c|}{ Package } & \multicolumn{1}{c}{ Role } & \multicolumn{1}{c}{ Authors } \\
\hline Adehabitat & Home range estimation & Calange \\
aspace & Measuring spatial distance & Remmel \& Buliung \\
spdep & Measuring spatial autocorrelation & Bivand \\
mvpart & CART models & Therneau \& Atkinson \\
MASS & Spatial GLMM & Venables \& Ripley \\
\hline
\end{tabular}

\section{Results}

\section{„Current” breeding range}

The grouping variables of the decision tree applied on the current breeding range scale were: „Forest”, "Large parcel arable lands" and "Grasslands”. The spatial GLMM fitted with these variables correctly classified $74 \%$ of the observations (Cohen's $\kappa=0.48,95 \%$ Confidence Interval: $0.3,0.67)$. The "Large parcel arable land" variable had no siginifcant effect, the "Grassland" variable had marginally significant positive effect, while the "Forest" variable had significantly negative effect, according to the model (Table 3.).

Table 3. The output of the spatial GLMM fitted on the presencelabsence of red-footed falcons at a colony within the „current” breeding range.

\begin{tabular}{c|c|c|c|c}
\hline & estimate & SE & t-value & p-value \\
\hline Intercept & -1.37 & 1.53 & -0.89 & 0.3746 \\
Grassland & 0.03 & 0.019 & 1.68 & 0.0599 \\
Forest & -0.52 & 0.20 & -2.58 & $\mathbf{0 . 0 1 6 4}$ \\
Large parcel arable lands & 0.013 & 0.019 & 1.01 & 0.4951
\end{tabular}

Although the „Large parcel arable land” had a significant grouping effect in the decision tree, it turned out to be non-significant in the spatial GLMM. This is probably due to the strong spatial autocorrelation of this variable. Presumably, decision trees overestimate the grouping effects of highly autocorrelated variables, hence the contradiction of the role of this variable in the different statistical analyses.

\section{„Historic” breeding range.}

The decision tree applied on the "historic" breeding range scale (i.e. the whole country) classified $90 \%$ of the observations correctly. The grouping variables were: „Roads”, „Water surface”, „Forest” and „Grassland”. The spatial GLMM fitted with these variables classified $87 \%$ of observations correctly (Table 6.). The classification of this model is also significantly deviating from random classification (Cohen's $\kappa=0.52$, 95\% Confidence Interval: 0.51, 0.78). All grouping variables of the decision tree stayed significant in the spatial GLMM. 
Table 4. The output of the spatial GLMM fitted on the presencelabsence of red-footed falcons at a colony within the ,historic” breeding range.

\begin{tabular}{c|c|c|c|c}
\hline & estimate & SE & t-value & p-value \\
\hline Intercept & -3.33 & 1.16 & -2.87 & 0.005 \\
Forest & -1.5 & 0.33 & -4.52 & $<0.001$ \\
Grassland & 0.042 & 0.01 & 3.53 & $<0.001$ \\
Road & -0.19 & 0.085 & 2.21 & 0.023 \\
Water surface & -1.07 & 0.4 & -2.63 & 0.008 \\
\hline
\end{tabular}

The significant „Road” variable is highly correlated with the ratio of „Settlement” variable (Spearman's rank correlation coefficient $=0.75, \mathrm{p}<0.0001$ ) within the potential home range, therefore it can be used as an indicator of human presence. If the "Settlement" variable occupied more than $25 \%$ percent of the potential home-range of a given colony, we classified it as urban colonies. Out of the 76 rookeries outside the current breeding range, 58 are classified as urban colonies. On the other hand, only 3 out of the 86 colonies within the current breeding range are classified as urban colonies. The „Forest" variable had a negative effect on the probability of red-footed falcon presence at a given colony on both spatial scales, although there is a large difference in the ratio of forests between the two breeding ranges. The "historic" model does not predict red-footed falcon presence at any of the colonies outside the current breeding range (Fig. 6.).

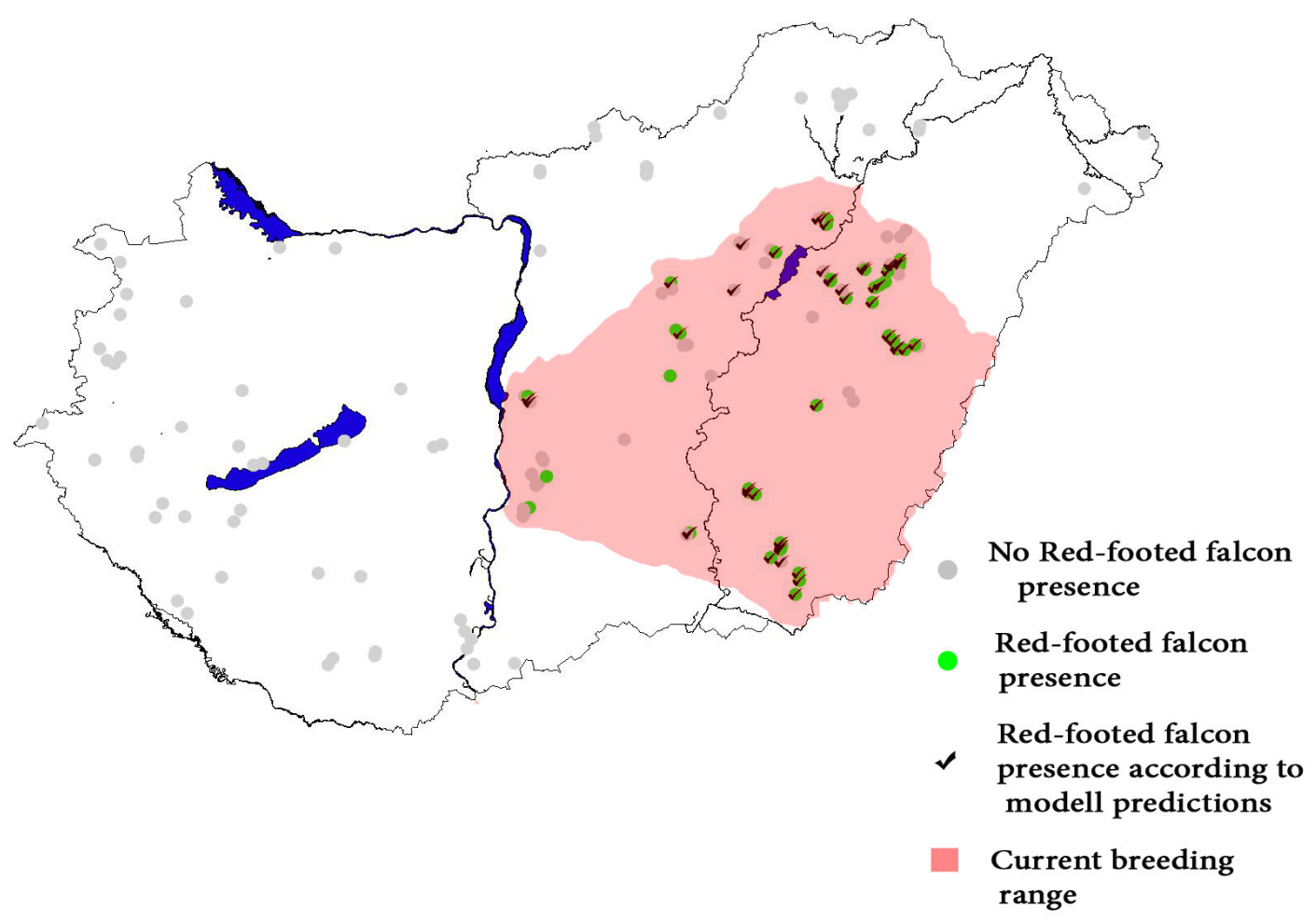

Figure 6. The predictons of the historic breeding range model. According to our model predictions, there are no colonies suitable for red-footed falcon breeding outside the current breeding range. 


\section{Discussion}

Although the classification of the model fitted on the current breeding range is moderately accurate (74\%), it reveals an interesting pattern in the case of the "Forest" variable. This variable has significant negative effect on the probability of red-footed falcon presence in models fitted on both spatial scales, even though the variable range is quite different. The CORINE can only differentiate forest patches larger than 4 ha, therefore the $3-4 \%$ of forests in the potential home ranges of colonies within the current breeding range practically mean a few small patches or one larger patch. The Goshawk (Accipiter gentilis) is a regular, well distributed (Haraszthy 1988) predator of the redfooted falcons (pers. obs., Bagyura \& Haraszthy 1994), occupying small to large forest patches for breeding. Therefore, the observed colony occupying pattern of red-footed falcons can be explained as a predator avoiding strategy (e.g. Brodie \& Formanowicz 1991, Fontaine \& Martin 2006).

The positive effect of grasslands was not as significant as expected in the current breeding range model. The habitat use analyses revealed that this species uses agricultural lands relatively often for hunting (Fehérvári et. al 2006), suggesting that the birds can substitute grasslands to a certain degree, similar to lesser kestrels (Tella et. al 1998), causing the "Grassland" variable's lower explanatory power. The significant difference between colonies outside the current breeding range and the ones currently occupied by red-footed falcons can be explained by two reasons: 1) the previously mentioned urbanization of rooks outside the current breeding range, and 2) that the landscape has been significantly transformed over the past decades. Source: Central Statistical Institute: http://portal.ksh.hu/pls/ksh/docs/hun/agrar/html/tabl1_3_1.html). Presumably, landscape modification has been greater outside the current breeding range, but most probably these two main causes acted synergistically to generate the current red-footed falcon breeding distribution. This presumption may be confirmed by the prediction map of the "historic" breeding range model, which does not predict redfooted falcon occurrence outside the current breeding range (Fig. 5.). Although our model variables derive from a coarse GIS database, and we only considered the distribution pattern of one year's red-footed falcon breeding distribution, our model predictions may aid the mid-term nature conservation strategy of this near threatened species. It is quite clear that - in the current situation - without the local redistribution of rookeries (i.e. from urban to natural habitats outside the current breeding range of red-footed falcons) there is a low chance of red-footed falcon breeding range reexpansion.

Acknowledgements. This work was partly supported by the "Conservation of the Red-footed falcon in the Pannon Region" LIFE NATURE program and OTKA T049157 grant and MME/BirdLife Hungary's Monitoring Centre. We are grateful for Anna Nagy and two anonymous reviewers who provided helpful comments on this manuscript and we thank every volunteer for their indispensable help in data collection.

\section{REFERENCES}

[1] Araújo M.B., New M. (2007): Ensemble forecasting of species distributions. -Trends in Ecology \& Evolution 22: 42-47

[2] Bagyura, J., Haraszthy, J. (1994): Adatok a héja (Accipiter gentilis) ragadozómadár- és bagolytáplálékához -Aquila, 101, pp. 89-92 
[3] Bagyura, J., Haraszthy, L., Szitta, T. (1996): Gyakorlati ragadozómadár-védelem. Magánkiadás. ISBN: 9630462842

[4] Bagyura, J., Palatitz, P. (2004): Fajmegőrzési tervek, Kék vércse (Falco vespertinus). KvVM TvH.

[5] Brodie, E.D., Formanowicz, D.R. (1991): Predator avoidance and antipredator mechanisms-distinct pathways to survival. - Ethol. Ecol. Evol. 3: 73-77.

[6] Bustamante, J. (1997): Predictive models for Lesser kestrel Falco naumanni distribution abundance and extinction in southern spain. - Biological Conservation 80: 153-160.

[7] del Hoyo, J., Elliot, A., Sargatal, J. (eds) (1994): Handbook of the Birds of the World. Vol. 2. New World Vultures to Guineafowl. - Lynx Edicions, Barcelona.

[8] Elith, J., Graham, C. E., Anderson, R.P., Dudík, M., Ferrier, S., Guisan, A., Hijmans, R.J., Huettmann, F., Leathwick, J.R., Lehmann, A., Jin Li,. Lohmann, L.G., Loiselle, B.A., Manion, G., Moritz, C., Nakamura, M., Nakazawa, Y., Overton, J.M.M., Peterson, T.A., Phillips, S.J., Richardson, K., Scachetti-Pereira, R.,. Schapire, R.E., Soberón, J., Williams, S., Wisz, M., Zimmermann, N. (2006): Novel methods improve prediction of species' distributions from occurrence data. - Ecography 29 (2): 129-151.

[9] Faraway, J. (2005): Extending the Linear Model with R - CRC Press

[10] Fehérvári, P., Neidert, D., Solt, Sz., Kotymán, L., Szövényi, G., Soltész, Z., Palatitz, P. (2006): Kék vércse élőhely preferencia vizsgálat - egy tesztév eredményei. - Heliaca: 5159.

[11] Fontaine, J. J., Martin, T. E. (2006): Parent birds assess nest predation risk and adjust their reproductive strategies. - Ecology Letters 9 (4): 428-434.

[12] Franco, A.M.A, Palmeirim, J.M., Sutherland, W.J. (2007): A method for comparing effectiveness of research techniques in conservation and applied ecology. - Biological Conservation (134) 1: 96-105.

[13] Franco, A.M.A, Sutherland, W.J. (2004): Modelling the foraging habitat selection of lesser kestrels: conservation implications of European Agricultural Policies. - Biological Conservation (120) 1: 63-74.

[14] Garcia, J.T., Morales, M.B., Martinez, J. et al. (2006): Foraging activity and use of space by Lesser Kestrel Falco naumanni in relation to agrarian management in central Spain. Bird Conservation International (16) 1: 83-95.

[15] Groning, J., Krause, S., Hochkirch, A. (2007): Habitat preferences of an endangered insect species, Cepero's ground-hopper (Tetrix ceperoi). - Ecological Research 22(55): 767-773.

[16] Guisan, A., Thuiller, W. (2005): Predicting species distribution: offering more than simple habitat models. - Ecology Letters 8 (9): 993-1009.

[17] Haraszthy, L. (1981) Contributions to the quantity conditions and hatching biology of red-foot falcons hatching in the Hortobagy 1973. - Aquila. 1981; 87: 117-122.

[18] Haraszthy, L. (ed) (1998): Magyarország madarai - Mezőgazda Kiadó, Budapest.

[19] Horváth, L. (1964): A kék vércse (Falco vespertinus L.) é s a kis őrgébics (Lanius minor $\mathrm{Gm}$.) élettörténetének összehasonlító vizsgálata II. A fiókák kikelésétől az őszi vonulásig - Vertebrata Hungarica VI. 1-2.

[20] Kalotás, Zs. (1984): A vetési varjú (Corvus frugilegus) állományfelmérése Magyarországon 1980 tavaszán. - Puszta (2)11: 109-121.

[21] Kalotás, Zs. (1987): A vetési varjú (Corvus frugilegus L.) hazai állományának felmérése 1984 tavaszán. - Állattani közlemények 74 (1-4): 65-76.

[22] Kalotás, Zs., Nikodémusz, E. (1981): Szelektív varjúirtás lehetősége a 3-klór-4metilanilin-hidroklorid anyaggal. 1. Etetési és szabadföldi vizsgálatok a vetési varjún (Corvus frugilegus L.). - Állattani közlemények 68(1-4): 89-96.

[23] Keve, A. Szijj, J. (1957): Distribution, biologie et alimentation du Faucon kobez Falco vespertinus L. en Hongrie - Alauda 25(1): 1-23. 
[24] Lopez-Lopez, P., Garcia-Ripolles, C., Soutullo, A. (2007): Identifying potentially suitable nesting habitat for golden eagles applied to 'important bird areas' design. - Animal Conservation 10 (2): 208-218.

[25] Negro, J.J., Hiraldo, F. (1993): Nest-site selection and breeding success in the lesser kestrel Falco naumanni. - Bird Study 40 (22): 115-119.

[26] Newton, I. (1979): Population Ecology of Raptors. - Poyser, Berkhamsted, UK

[27] Noss, R.F., O'Connell, M.A., Murphy, D. D. (1997): The science of conservation planning: Habitat conservation under the endangered species act. - Island Press

[28] Ozaki, K., Isono, M., Kawahara, T., Iida, S., Kudo, T., Fukuyama, K. (2006): A Mechanistic approach to evaluation of umbrella species as conservation surrogates. Conservation Biology 20 (5): 1507-1515.

[29] Palatitz P., Solt Sz., Fehérvári P. (2005): Kékvércse-védelmi Munkacsoport 2005. évi beszámolója. - Heliaca: 12-17

[30] Palatitz P., Solt Sz., Fehérvári P., Neidert D. és Bánfi P. (2006): Kékvércse-védelmi Munkacsoport 2006. évi beszámolója. - Heliaca: 16-24

[31] Palomino, D. Carrascal, L.M. (2007): Habitat associations of a raptor community in a mosaic landscape of Central Spain under urban development - Landscape and Urban Planning 83 (4): 268-274.

[32] Pearce, J. L., Kirk, D. A. P., Lane, C. P., Mahr, M. H., Walmsley, J., Casey, D., Muir, J.E., Hannon, S., Hansen, A., Jones, K. (2008): Prioritizing avian conservation areas for the Yellowstone to Yukon Region of North America. - Biological Conservation 141(4): 908-924.

[33] R Development Core Team (2007): R: A language and environment for statistical computing. - R Foundation for Statistical Computing, Vienna, Austria.

[34] Roberge, J.M., Angelstram, P. (2004): Usefulness of the umbrella species concept as a conservation tool. - Conservation Biology 18 (1): 76-85.

[35] Robles, H., Ciudad, C., Vera, R., Olea, P.P.,. Purroy, F.J., Matthysen, E. (2007): Sylvopastoral management and conservation of the middle spotted woodpecker at the south-western edge of its distribution range. - Forest Ecology and Management. 242 (23): $343-352$.

[36] Sergio, F., Newton, I., Marchesi, L., Pedrini, P. (2006): Ecologically justified charisma: preservation of top predators delivers biodiversity conservation. - Journal of Applied Ecology 43 (6): 1049-1055.

[37] Solt Sz., Pigniczki Cs., Utassy T., Fehérvári P. és Palatitz P. (2005): Kiskunsági kék vércse kitekintő - avagy egy ígéretes müfészek telep kialakításának tapasztalatai. Heliaca: 67-71.

[38] Solt, Sz. (2008): Vetési varjú konfliktus kezelési javaslatok tervezet. MME gondozásban. In Press.

[39] Solt, Sz., Pigniczki, Cs., Utassy, T., Fehérvári, P., Palatitz, P. (2005): Kiskunsági kék vércse kitekintő - avagy egy ígéretes müfészek telep kialakításának tapasztalatai. Heliaca: 67-71.

[40] Tella, J.L., Forereo, M.G., Hiraldo, F., Donazar, J.A. (1998): Conflicts between Lesser Kestrel Conservation and European Agricultural Policies as Identified by Habitat Use Analyses. - Conservation Biology 12 (3): 593-604

[41] Toschik, P.C., Christman, M.C., Rattner, B.A., Ottinger, M.A. (2006): Evaluation of osprey habitat suitability and interaction with contaminant exposure. - Journal of Wildlife Management 70 (44): 977-988.

[42] Tóth, I. és Marik, P. (1999): Kék vércse felmérés. - Madártávlat 4: 4-5.

[43] Vertse, A. (1943): A vetési varju elterjedése, táplálkozása és mezőgazdasági jelentősége Magyarországon. - Aquila (50): 142-248.

[44] Xuezhi, W., Weihua, X., Zhiyun, O., Jianguo, L., Yi, X., Youping, C., Lianjun, Z., Junzhong, H. (2008): Application of ecological-niche factor analysis in habitat assessment of giant pandas -Acta Ecologica Sinica 28 (2): 821-828. 